\title{
THE NUTRITIONAL REQUIREMENTS OF PROTEIN FOR SINAI COCKS
}

\author{
M.E. Soltan and Manal K. Abou-Elnaga \\ Poultry and Fish Production Department, Faculty of Agriculture, Menoufia University, Shebin El-Kom, \\ Menoufia, Egypt.
}

(Received 6/2/2019, accepted 24/3/2019)

\section{SUMMARY}

\begin{abstract}
$\mathrm{T}$ he present study was conducted in order to determine the protein requirements of Sinai cocks males as a local strain by feeding different crude protein (CP) levels (Control: 17\%, Medium: 15\% or Low: $13 \%)$ on their reproductive performance and semen quality. Forty five male of local strain Sinai Bedouin ( 32 weeks old) were divided into three equal groups, 15 male/ group with 3 replicates each, having nearly similar body weights $(1.40 \mathrm{~kg})$ and located housed in individual cages. The experiment extended for 6 weeks. Results revealed that feed intake and protein intake were significantly reduced as the dietary crude protein level was decreased $(13 \% \mathrm{CP}$, being 86 and $11.11 \mathrm{~g} / \mathrm{cock} /$ day compared to $96,93 \mathrm{~g}$ feed/cock/day and $16.34,13.24 \mathrm{~g} \mathrm{CP} /$ cock/ day in cocks fed the control (17\%) and the medium (15\%) crude protein diets, respectively). Neither fertility nor hatchability was affected, while significant increase in semen volume and motility were noticed with reducing dietary crude protein levels. The greater amounts of semen volume and the lowest semen concentration $\left(226 \times 10^{7} / \mathrm{ml}\right)$, were recorded for males fed the lowest dietary crude protein diet $(13 \%)$ in comparison with the other feeding groups. Blood glucose, total protein and triglycerides were decreased by reducing dietary crude protein levels. Meanwhile, blood serum createnine, total cholesterol and ALT and AST enzymes were increased by reducing dietary crude protein levels.
\end{abstract}

Keywords: Sinai cocks, semen quality, low protein and nutrition.

\section{INTRODUCTION}

Chickens vary greatly according to the purpose for which they have been developed. Those intended for the production of eggs for human consumption (Leghorn-type) have a small body size and are prolific layers, whereas those used as broilers or broiler breeders (meat-type) have rapid growth rates and a large body size. They are less efficient egg layers. Also, cocks must have a special diet to maintain fertility without increasing cost feeding.

The protein level of poultry diet is one important factor for hatching characters and embryonic mortality. The nutrition of breeder males is often overlooked and they are often fed a female ration which consists of a higher nutrient content than that required, due to the impracticality of feeding a separate ration. Overfeeding of this nutrient, besides the cost implication, may even result in negative effects on male breeder fertility (Tyler and Bekker, 2012).

Recently, Garland (2019) reported that the concept of commercial "low protein diet" used in the United Kingdom (UK) will be put into context both with typical Australian diets but also within the farm work of the commercial environment that may has a significant impact on how chickens are reared.

It is not realistic to suggest that the current UK broiler chicken diets are notably lower in protein than those used elsewhere. However, there is pressure from a number of areas to reduce crude protein whilst maintaining diets performance levels. Environmental controls are guiding farmers towards using lower protein and cost efficiency is clearly major factor in maximizing the efficient use of protein.

There is however inconsistency on the reports in effects of feeding males a female ration on male reproductive efficiency and this may be due to the inaccuracy of the various measurement techniques used to gauge male fertility. 


\section{Soltan and Abou-Elnaga}

The influence of the male breeder in egg fertility is of greater importance than the contribution of the female (Wolc et al., 2009) and infertility problems in poultry have often been blamed on the male (Etches, 1996).

Semen concentration was lower in caged broiler breeder males fed on $16 \% \mathrm{CP}$ diet than in those fed on $12 \% \mathrm{CP}$ from 21 to $66 \mathrm{wks}$ of age and increasing the amount of feed did not produce more semen or increase sperm concentration (Hocking and Bernard, 1997).

Moreover, volume and color of semen sample are also evaluated to determine the teasing of male and presence of any lesion or infection in genital tract (Sack, 1983).

It is impossible to ignore $\mathrm{CP}$ in male fertility as it plays an integral role in reproduction efficiency of poultry breeders at all stages (Zhang et al., 1999). Separate-sex feeding and changes in genetics have prompted the understanding of male nutritional requirements separately from females.

Therefore, the purpose of this study was to test the effects of feeding different levels of dietary crude protein intake in Saini cocks strain as a local strain males on their reproductive performance and semen quality to determine their crude protein requirements.

\section{MATERIALS AND METHODS}

The present study was conducted in the Poultry Farm and the Poultry Nutrition Laboratory, Poultry and Fish Production Department, Faculty of Agriculture, Menoufia University, Egypt.

\section{Experimental design:}

Forty five local strains Sinai Bedouin male (32 wks old) were divided into three equal groups, fifteen male/ group with three replicates each, having nearly similar body weights $(1.4 \mathrm{~kg})$ and housed in individual cages, the history of Sinai local strain was obtained by Soltan et al. (2018). The three groups were assigned and allocated to one of the following three isocaloric dietary treatments, $17 \% \mathrm{CP}$ as the control group $\left(\mathrm{T}_{1}\right)$, medium $\left(\mathrm{T}_{2}, 14.99 \% \mathrm{CP}\right)$ and low $\left(\mathrm{T}_{3}, 12.99 \% \mathrm{CP}\right)$, until 38 wks of age. Males were submitted to the same managerial condition of layer farms, given feed and water ad libtium. Artificial light was used beside the normal day light to provide 16 hour photo period $16 \mathrm{~L}: 8 \mathrm{D}$ ).

Males were individually weighed at the beginning and at the end of the experimental period and feed intake ((FI) was recorded and crude protein intake was calculated according to the equation:

$$
\mathrm{CP} \text { intake }(\mathrm{g} / \text { bird })=\{\mathrm{FI}(\mathrm{g} / \text { bird }) \times \mathrm{CP} \% \text { (in the diet })\} \div 100
$$

The composition of the experimental diets (Table 1) was calculated to meet the nutrient requirements of NRC (1994).

During the experimental periods ( $6 \mathrm{wks})$ males were fed the experimental diets for a preliminary period of 2 wks as adaptation to the experimental conditions.

\section{Semen collection:}

Each male was trained for semen collection using the abdominal massage methods squeezing the capulatory organs to obtain semen as described by Lake (1962) and Kalamah et al. (2002).

Males were trained to produce semen samples biweekly. Serum samples were used for artificial insemination $\left(1 \delta^{\lambda}: 3\right.$ 우 $)$, a greater than the normal dose to ensure that the number of spermatozoa would not be a limiting factor and that the results would be a function of sperm quality and for evaluation of semen parameters.

The appearance of semen color was scored by visual examination on a scale of 1 of 3 (Peters et al., 2008), where: $1=$ creamy white, $2=$ between opaque and creamy - white and $3=$ opaque.

Sperm concentration was measured using Hemocytometer which is used for counting blood cells. The concentration of sperm per volume was estimated as the following formula:

$$
\begin{aligned}
& \mathrm{C}=50,000 \times \mathrm{N} \times \mathrm{D} \quad \text { Where: } \mathrm{C}=\text { concentration of sperm per volume }(\mathrm{ml}) . \\
& \mathrm{N}=\text { number of spermatozoa counted, } \mathrm{D}=\text { dilution rate (Peters } \text { et al., 2008). }
\end{aligned}
$$


Table (1): Ingredients and nutrient composition of the experimental diets.

\begin{tabular}{|c|c|c|c|}
\hline \multirow[b]{2}{*}{ Item } & \multicolumn{3}{|c|}{ Dietary treatment } \\
\hline & $\begin{array}{c}\mathrm{T}_{1} \\
(17 \% \mathrm{CP})\end{array}$ & $\begin{array}{c}\mathrm{T}_{2} \\
(15 \% \mathrm{CP})\end{array}$ & $\begin{array}{c}\mathrm{T}_{3} \\
(13 \% \mathrm{CP})\end{array}$ \\
\hline \multicolumn{4}{|l|}{ Ingredient, \%: } \\
\hline Ground yellow corn $(8.5 \%)$ & 60.75 & 63.95 & 66.80 \\
\hline Soybean meal ( $44 \% \mathrm{CP})$ & 22.40 & 16.55 & 10.30 \\
\hline $\begin{array}{l}\text { Wheat bran }(15.3 \%) \\
\text { Di-calcium phosphate } \\
\text { Limestone, ground }\end{array}$ & $\begin{array}{l}12.80 \\
2.00 \\
1.35\end{array}$ & $\begin{array}{l}14.80 \\
2.05 \\
1.40\end{array}$ & $\begin{array}{l}18.10 \\
2.10 \\
1.40\end{array}$ \\
\hline Vitamin and mineral premix ${ }^{1}$ & 0.30 & 0.30 & 0.30 \\
\hline Salt (Sodium chloride) & 0.30 & 0.30 & 0.30 \\
\hline DL-methionine $^{2}$ & 0.10 & 0.25 & 0.20 \\
\hline $\begin{array}{l}\text { Lvsine } \\
\text { Total }\end{array}$ & $\begin{array}{l}000 \\
100\end{array}$ & $\begin{array}{l}0.40 \\
100\end{array}$ & $\begin{array}{l}0.50 \\
100\end{array}$ \\
\hline \multicolumn{4}{|c|}{ Calculated energy and nutrient content ${ }^{3}$ : } \\
\hline Crude protein $(\%)$ & 16.98 & 14.98 & 12.99 \\
\hline $\begin{array}{l}\mathrm{ME}, \mathrm{kcal} / \mathrm{kg} \text { diet } \\
\mathrm{C} / \mathrm{P} \text { ratio }\end{array}$ & $\begin{array}{c}2703 \\
159\end{array}$ & $\begin{array}{c}2705 \\
181\end{array}$ & $\begin{array}{c}2705 \\
208\end{array}$ \\
\hline $\begin{array}{l}\text { Calcium }(\mathrm{g} / \mathrm{kg}) \\
\text { Available phosphorus }(\mathrm{g} / \mathrm{kg})\end{array}$ & $\begin{array}{l}1.01 \\
0.50\end{array}$ & $\begin{array}{l}1.03 \\
0.50\end{array}$ & $\begin{array}{l}1.03 \\
0.51\end{array}$ \\
\hline Determined protein content ${ }^{4}(\%)$ & 16.75 & 14.85 & 13.10 \\
\hline \multicolumn{4}{|c|}{$\begin{array}{l}{ }^{1} \text { Supplied per } \mathrm{kg} \text { of diet: Vitamin A } 12,000 \mathrm{IU} \text {, vitamin } \mathrm{D}_{3} 3,000 \mathrm{IU} \text {, vitamin } E 40 \mathrm{mg} \text {, vitamin } \mathrm{K}_{3} 3 \mathrm{mg} \text {, vitamin } \mathrm{B}_{1} 2 \mathrm{mg} \\
\text { vitamin } B_{2} 6 \mathrm{mg} \text {, vitamin } B_{6} 5 \mathrm{mg} \text {, vitamin } B_{12} 0.02 \mathrm{mg} \text {, niacin } 45 \mathrm{mg} \text {, biotin } 0.075 \mathrm{mg} \text {, folic acid } 2 \mathrm{mg} \text {, pantothenic aci } \\
12 \mathrm{mg} \text {, manganese } 100 \mathrm{mg} \text {, zinc } 600 \mathrm{mg} \text {, iron } 30 \mathrm{mg} \text {, copper } 10 \mathrm{mg} \text {, iodine } 1 \mathrm{mg} \text {, selenium } 0.2 \mathrm{mg} \text {, and cobalt } 0.1 \mathrm{mg} \text {. } \\
{ }^{2} \text { DL-Methionine, Met AMINO® (DL-2-amino-4-(methyl-thio)-butane acid by Feed Grade } 99 \% \text { (EU). } \\
{ }^{3} \text { The composition of the experimental diets was based on NRC (1994) tabulated values for feedstuffs. }\end{array}$} \\
\hline
\end{tabular}

\section{Livability and abnormal sperm count:}

Percentages of live, dead and abnormal sperms were estimated by different staining technique using eosin - nigrosin stain (Kalamah et al., 2002). Sperm motility was scrod according to arbitrary scheme of classification in range from $1-5$ grades (Nagae et al., 1987).

\section{Fertility and hatchability percentage:}

Eggs were collected twice a day post insemination and stored in a cold room until hatching. Therefore, eggs were set for incubation at an eggshell temperature of $37.8{ }^{\circ} \mathrm{C}$ and relative humidity $55 \%$ in a commercial hatchery (Poultry Research Farm, Faculty of Agriculture, Menoufia University, Egypt). On day 18 of incubation, all eggs were transferred to the hatchery. After $72 \mathrm{~h}$ post-hatching, chicks were transferred from the hatchery and placed in the floor pens. Fertility and hatchability percentages were calculated.

\section{Blood serum biochemical parameters:}

Blood samples were collected from the wing veins of two cocker from each replicate into un-heparinized tubes and centrifuge at $3500 \mathrm{rpm}$ for 15 minutes. Serum concentrations of glucose, total protein (TP), albumin (ALB), createnine, cholesterol, triglyceride, AST and ALT enzymes were determined according to AOAC (2003).

\section{Statistical analysis:}

Data were statistically analyzed by the completely randomized design using SPSS (2011) program and the differences among means were determined using Duncan's multiple range test (Duncan, 1955). Percentages were transformed to the corresponding arcsine values before performing statistical analysis. The following statistical model was used:

$$
\mathrm{Y}_{\mathrm{ij}}=\mu+\alpha_{\mathrm{i}}+\mathrm{E}_{\mathrm{ij}}
$$


Where: $Y_{i j}=$ an observation. $\mu=$ Overall mean. $\alpha_{i}=$ effect of treatment $(\mathrm{I}=1,2,3)$, and $E_{i j}=$ Random error.

\section{RESULTS AND DISCUSSION}

Means of cock's performance (initial, final body weight, feed intake and protein intake) are presented in Table (2). Data revealed that body weight was not affected by the different dietary crude protein levels (17, 15 and $13 \%$ ) supplementation, this is may be due to that cocks reached the sexual and physical maturity. Feed intake $(86 \mathrm{~g} / \mathrm{cock} / \mathrm{d})$ and protein intake $(11.11 \mathrm{~g} / \mathrm{cock} / \mathrm{d})$ were significantly reduced as the dietary crude protein level decreased (13\%) compared to 96,93 and 16.34,13.24g/ cock/ d, respectively in cocks fed the adequate $(17 \%)$ and the medium $(15 \%)$ crude protein diets. This is maybe related to the differences in $\mathrm{C} / \mathrm{P}$ ratio or because the diet contains a high amount of wheat bran to reduce protein levels, which takes an area in the digestive tract, where the amount of feed intake was reduced, so feed efficiency was improved and the cost of feed was also reduced.

Table (2): Effect of different dietary crude protein levels on the performance of Sinai Bedouin cocks during the experimental period (Mean \pm S.E.).

\begin{tabular}{|c|c|c|c|c|}
\hline \multirow[b]{2}{*}{ Item } & \multicolumn{3}{|c|}{ Dietary treatment } & \multirow[b]{2}{*}{ Sig } \\
\hline & $\begin{array}{c}\mathrm{T}_{1} \\
(17 \% \mathrm{CP})\end{array}$ & $\begin{array}{c}\mathrm{T}_{2} \\
(15 \% \mathrm{CP})\end{array}$ & $\begin{array}{c}\mathrm{T}_{3} \\
(13 \% \mathrm{CP})\end{array}$ & \\
\hline Initial cock body weight $(\mathrm{Kg})$ & $1.49 \pm 0.25$ & $1.45 \pm 0.20$ & $1.48 \pm 0.33$ & NS \\
\hline Final cock body weight (Kg) & $1.63 \pm 0.31$ & $1.59 \pm 0.27$ & $1.63 \pm 0.26$ & NS \\
\hline Feed intake/ cock/ d (g) & $96^{\mathrm{a}} \pm 0.93$ & $93^{\mathrm{b}} \pm 1.10$ & $86^{1,2 \mathrm{c}} \pm 1.04$ & $*$ \\
\hline Protein intake/cock/ d $(\mathrm{g})^{3}$ & $16.34^{\mathrm{a}} \pm 0.28$ & $13.24^{\mathrm{b}} \pm 0.65$ & $11.11^{\mathrm{c}} \pm 0.21$ & $*$ \\
\hline Feeding coast, L. E/cock. & 4.90 & 4.70 & 4.50 & \\
\hline
\end{tabular}

Neither fertility $(98.67,98.33$ and $98.67 \%)$ nor hatchability $(77.15,77.63$ and $76.92 \%)$ of Sinai eggs from hens fertilized by cocks fed different crude protein levels (17, 15 and 13\%) were significantly affected (Table 3). There were significant increases in the semen volume and semen motility with reducing dietary crude protein levels. The greater amounts of semen volume was recorded for males fed the lowest dietary crude protein $(13 \%)$ followed by those fed medium (15\%) and adequate crude protein diet (17\%) they were 1, 0.78 and $0.70 \mathrm{ml}$, respectively (Table 3 and Figures 1 and 2).

Table (3): Effect of different dietary crude protein levels on semen quality, fertility and hatchability of Sinai cocks during the experimental period (Mean \pm S.E.).

\begin{tabular}{lcccc}
\hline & \multicolumn{3}{c}{ Dietary treatment } & Sig. \\
\cline { 2 - 4 } Item & $\mathrm{T}_{1}$ & $\mathrm{~T}_{2}$ & $\mathrm{~T}_{3}$ & $(13 \% \mathrm{CP})$ \\
\hline Semen volume $(\mathrm{ml})$ & $0.70^{\mathrm{b}} \pm 0.05$ & $0.78^{\mathrm{b}} \pm 0.04$ & $1.00^{1,2 \mathrm{a}} \pm 0.09$ & $*$ \\
Semen color & $4 \pm 0.10$ & $3 \pm 0.08$ & $3 \pm 0.05$ & $\mathrm{NS}$ \\
Semen concentration $\left(\times 10^{7} / \mathrm{ml}\right)$ & $306^{\mathrm{a}} \pm 0.58$ & $282^{\mathrm{b}} \pm 0.35$ & $226^{\mathrm{c}} \pm 0.73$ & $*$ \\
Semen motility $(\%)$ & $65^{\mathrm{b}} \pm 2.89$ & $67.67^{\mathrm{b}} \pm 1.45$ & $94.67^{\mathrm{a}} \pm 2.60$ & $*$ \\
Normality $(\%)$ & $92^{\mathrm{a}} \pm 0.58$ & $87^{\mathrm{c}} \pm 0.77$ & $90^{\mathrm{a}} \pm 0.55$ & $*$ \\
Live sperm $(\%)$ & $88 \pm 0.71$ & $85 \pm 0.53$ & $87 \pm 0.49$ & $\mathrm{NS}$ \\
Fertility $(\%)$ & $98.67 \pm 0.33$ & $98.33 \pm 0.33$ & $98.67 \pm 0.81$ & $\mathrm{NS}$ \\
Hatchability $(\%)$ & $77.15 \pm 0.57$ & $77.63 \pm 0.34$ & $76.92 \pm 0.33$ & $\mathrm{NS}$ \\
\hline
\end{tabular}

${ }^{\prime}$ means \pm S.E. of 3 replicates / treatment.

${ }^{2} a, b, c \ldots . . . .$. etc: Means within the same row with different superscripts are significantly different $(\mathrm{P}<0.05)$ 


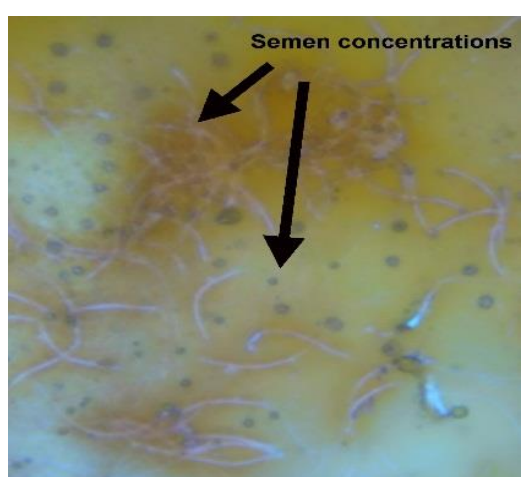

Figure (1): Adequate crude protein diet $(17 \%)$

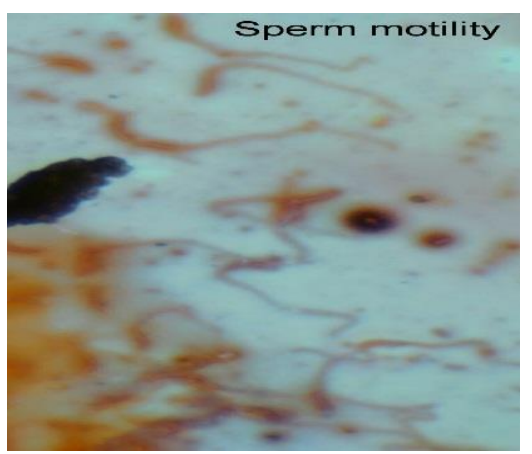

Figure (2): Adequate crude protein diet (17\%)

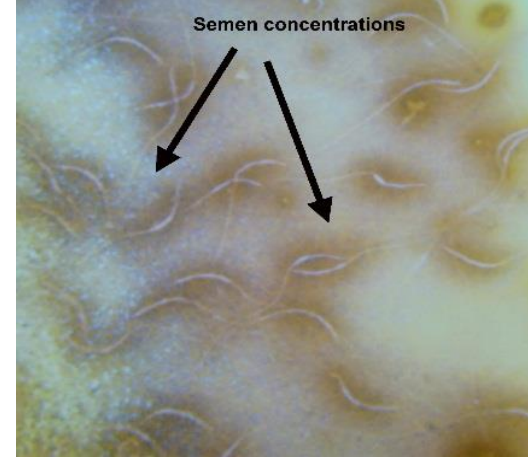

Medium crude protein diet (15\%)

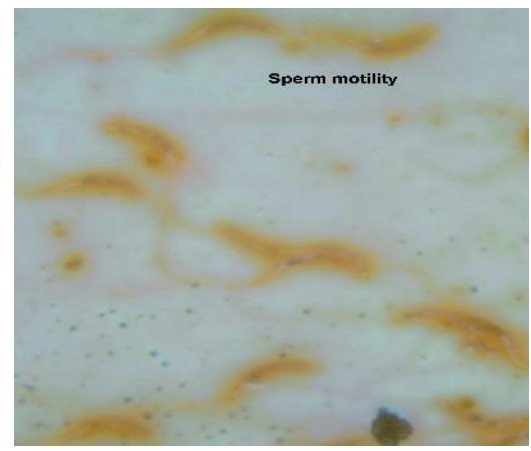

Medium crude protein diet (15\%)

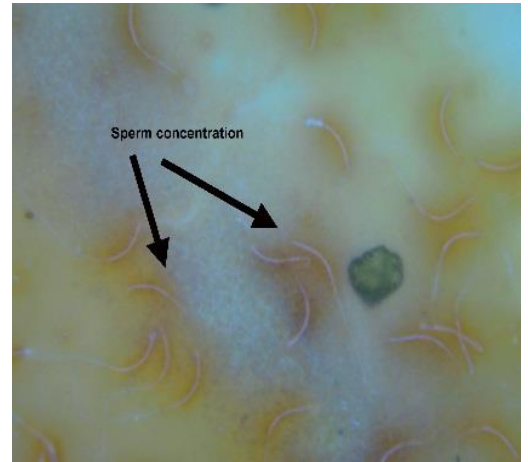

Low crude protein diet (13\%)

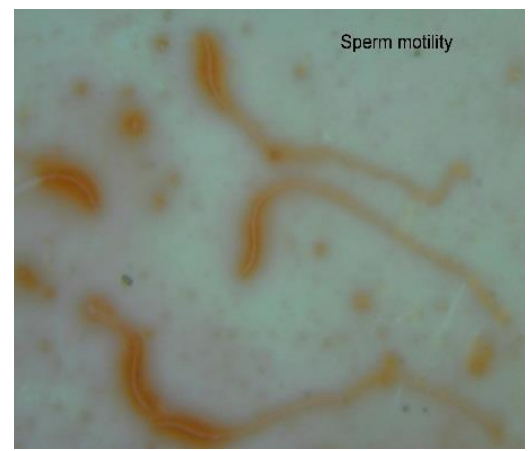

Low crude protein diet (13\%)

The variation in semen volume among groups fed different crude protein diet may be due to that increasing the percentage of dietary crude protein diet increased the sperm concentration and reduced its volume. Whereas, semen concentrations and normality were significantly reduced with reducing dietary crude protein levels. Although no differences were observed in the number of live sperm or semen color with reducing dietary crude protein.

Males fed $13 \%$ crude protein concentration produced the lowest semen concentration $\left(226 \times 10^{7} / \mathrm{ml}\right)$, although it have the same fertility percentage and the highest sperm motility (94.67\%) compared to 65 and $67.67 \%$ in males fed adequate $(17 \%)$ or medium $(15 \%)$ protein concentrations. Also, the present results showd that the differences among the different dietary groups in their live sperm $\%$ were not significant, while the differences were significant in normality.

These results are in agreement with Hafez (1978) who stated that the differences in volume and sperm concentration of the domestic fowl semen depends largely on the relative concentration of the various reproductive gland, the number of sperms that could be obtained from a breed / strain.

Wilson et al. (1987) reported that 12 or $14 \%$ CP could be given to male broiler breeders without affecting body weight, semen volume and sperm concentration. They added that males fed the 12 and $14 \%$ dietary CP diet significantly produced more semen from 27 to 30 weeks of age than those given higher CP levels (16 or $18 \%)$.

However, the proportion of males producing semen was declined with increasing CP content at 18 to 64 wks of age (Hocking and Duff 1989). Males fed 11\% CP diets had higher fertility (hatching eggs) than those on $16 \%$ CP diets (Hocking, 1990).

The proportion of males that produced semen was greater when the feed contained 9 to $12 \%$ CP than 15 to $18 \%$ CP (Wilson et al., 1987). Also, semen volume was affected by CP levels (12, 15 and 18\%). 
Van Emous et al. (2018) noted that during phase 1 (22: 34wks) and phase 2 (35: $46 \mathrm{wks})$ fertility and hatchability was not affected by reductions in dietary crude protein levels (13 to $11.5 \%)$. Some authors did not observe an effect of dietary protein levels on incubation traits (Mejia et al., 2012), although others showed that feeding poultry breeders a high protein levels during the laying period decreased fertility (Ekmay et al., 2013).

Wilson et al. (1988) showed no effect of feeding 9, 12 or $15 \%$ protein were observed on semen volume, concentration, number of spermatozoa ejaculated or spermatogenic activity. No differences in sperm volume, sperm concentration, total sperm yield and the proportion of males producing semen were observed from males fed either 8 or 12\% CP (Revington et al., 1991). There were no differences in fertility between males fed 12 or 16\% CP (Hocking and Bernard, 1997).

Fontana et al. (1990) found no differences in semen concentration or testes weight, but fertility as a measured by hatchability was significantly lower in the $a d$ - libitum fed group. This suggest that low fertility is a function of the actual fertilizing ability of the sperm cells and not the inability to produce spermatozoa which is estimated by the sperm concentration methods at 65 weeks of age that reported for males fed 12 or $14 \% \mathrm{CP}$ to achieve either 90 or $100 \%$ of the recommended body weight, respectively.

Table (4): Effect of different dietary crude protein levels on some serum biochemical parameters of Sinai cocks during the experimental period (Mean \pm S.E.).

\begin{tabular}{lcccc}
\hline & \multicolumn{3}{c}{ Dietary treatment } & Sig. \\
\cline { 2 - 4 } Item & $\mathrm{T}_{1}$ & $\mathrm{~T}_{2}$ & $\mathrm{~T}_{3}$ & $(13 \% \mathrm{CP})$ \\
& $(17 \% \mathrm{CP})$ & $(15 \% \mathrm{CP})$ & $\mathrm{NS}$ \\
Glucose $(\mathrm{mg} / \mathrm{dl})$ & $214 \pm 3.46$ & $208 \pm 5.01$ & $197 \pm 3.28$ & $\mathrm{NS}$ \\
Total protein $(\mathrm{mg} / \mathrm{dl})$ & $4.30 \pm 0.12$ & $4.20 \pm 0.16$ & $3.85 \pm 0.15$ & $* 1.20$ \\
Albumin $(\mathrm{mg} / \mathrm{dl})$ & $1.75^{\mathrm{a}} \pm 0.30$ & $1.75^{\mathrm{a}} \pm 0.09$ & $1.50^{1,2 \mathrm{~b}} \pm 0.06$ & $*$ \\
Createnine $(\mathrm{mg} / \mathrm{dl})$ & $0.72 \pm 0.06$ & $0.73 \pm 0.08$ & $0.85 \pm 0.01$ & $\mathrm{NS}$ \\
Total cholesterol $(\mathrm{mg} / \mathrm{dl})$ & $89.67 \pm 2.88$ & $98 \pm 5.77$ & $101 \pm 9.24$ & $\mathrm{NS}$ \\
Triglyceride $(\mathrm{mg} / \mathrm{dl})$ & $94^{\mathrm{a}} \pm 1.15$ & $90^{\mathrm{b}} \pm 1.54$ & $89^{\mathrm{b}} \pm 0.58$ & $*$ \\
AST $(\mathrm{U} / \mathrm{L})$ & $43 \pm 6.93$ & $48 \pm 5.77$ & $59 \pm 2.31$ & $\mathrm{NS}$ \\
ALT (U/ & $60.33^{\mathrm{b}} \pm 1.45$ & $66.67^{\mathrm{ab}} \pm 9.53$ & $86^{\mathrm{a}} \pm 3.46$ & $*$ \\
\hline
\end{tabular}

${ }^{I}$ means \pm S.E. of 3 replicates / treatment.

${ }^{2} a, b, c \ldots . . . . . e t c:$ Means within the same row with different superscripts are significantly different $(P<0.05)$.

Zhang et al. (1999) noted that semen volume was reported to be higher in males fed $12 \%$ vs. $16 \%$ CP from 28 to 36 weeks of age, but sperm concentration was not affected. Birds fed isocaloric diets containing 9 to $12 \% \mathrm{CP}$ before sexual maturity had similar semen volume, sperm concentration, testes weight, and duration of semen production.

Mohiti-Asli et al., (2012) found that fertility, hatchability of total and fertile eggs, and embryonic mortality of hen diet with high protein (CP $17.4 \%$ ) were higher than those of hen fed diet with low protein (CP $14.5 \%$ ). These results are not consistent with those of Ugurlu et al. (2017) who found that the highest fertility $(88.76 \%)$ and hatchability $(71.91 \%)$ were determined for the $15 \%$ crude protein diet.

Data in Table (4) showed that blood serum glucose and total protein were decreased by reducing dietary crude protein levels but not significant. Meanwhile, createnine, total cholesterol and AST enzyme were increased by reducing the dietary crude protein levels and also not significant. Results indicated that serum lipid parameters and enzyme activities (ALT) were significantly increased with reducing dietary crude protein supplementations. 


\section{CONCLUSION}

According to the results of the present study, it is concluded that feeding Sinai cocks low crude protein diet $(13 \%)$ is possibly the appropriate crude protein level for optimal semen production and reducing feeding cost under the same experimental condition.

\section{REFERENCES}

AOAC (2003). Association of Official Analysis Chemists. 17th ed Assoc. Off. Anal. Chem., Arlington, V A.

Duncan, D.B. (1955). Multiple range and multiple F tests. Biometrics .1:11- 42.

Ekmay, R. D., M. De Beer, S. J. Mei. M. Managi and C. N. Coon (2013). Amino acid requirements of broiler breeders at peak production for egg mass, body weight and fertility. Poul. Sci., 92: 992 - 1006.

Etches, R. J. (1996). Reproduction in Poultry, CAB Inter. Camb., U. K., 208 - 262.

Fontana, E.A., W.D., Weaver Jr. and H.P., Van Krey (1990). Effects of various feeding regimens on reproduction in broiler-breeder males. Poult. Sci., 69: 209 -216.

Garland, P. W. (2019). The challenges confronting chicken meat producers in Great Britain in relation to low protein diets. Zootecnica international No. 2: 44- 47.

Hafez, E. S. E. (1978). Reproduction in farm animals, $2^{\text {nd }}$ Ed. Philadelphia, PA, USA, Lea and Febiger, 455497.

Hocking, P.M. (1990). The relationships between dietary crude protein, body weight, and fertility in naturally mated broiler breeder males. Br. Poult. Sci., 31: 743 - 757.

Hocking, P.M. and R., Bernard (1997). Effects of dietary crude protein content and food intake on the production of semen in two lines of broiler breeder males. Br. Poult. Sci., 38: 199 - 202.

Hocking, P.M. and S.R.I., Duff (1989). Musculo-skeletal lesions in adult male broiler breeder fowls and their relationships with body weight and fertility at 60 weeks of age. Br. Poult. Sci., 30: 777 - 784.

Kalamah, M. A. A.; M. M. El-Nady; F. H. Abdou and E. K. Esa (2002). Effect of heat stress and vitamin C on some productive traits and physiological aspects in chickens. Minufiya Agric. Res., 27: 57 - 74.

Lake, P. E. (1962). Artificial insemination in poultry. In: Maile, J. P .(eds). The semen animals and A. I. Commonwealth Agric. Bureau, Bucks, England, pp: 331-335.

Meija, L., C. D. Mcdaniel and A. Corzo (2012). Dietary influence of digesstable lysine concentration on Cobb 500 hen broiler breeder reproductive performance. Poul. Sci., 91: 426 - 431.

Mohiti-Asli M, M. Shivazad, M Zaghari, M Rezaizan, S Aminzadeh and GG. Mateos (2012). Effects of feeding regimen, fiber inclusion and crude protein content of the diet on performance and egg quality and hatchability of eggs of broiler breeder hens. Poul. Sci., 91:3097 - 3106.

Nagae, T.; K. Nobukuni and H. Nishiyama (1987). Effect of thyroid hormone deficiency after sexual maturity on weights of male genital organs and semen quality in domestic fowls. Japanese Poult. Sci., 24: $1,28-72$.

NRC (1994). Nutrient requirements of Poultry. National Research Council, $9^{\text {th }}$ Ed. National Academy Press, Washington, DC, USA.

Peters, S.O.; B. O. Iiori; M. O. Ozoje; C. O. N. Ikeobi and O. A . Adebambo (2008). Semen quality traits of seven strain of chickens raised in the humid tropics. Inter. J. of Poult. Sci., 7 (10): 949 - 953.

Revington, W.H., E.T., Moran and G.R., McDaniel (1991). Performance of broiler breeder males given low protein feed. Poult. Sci., 70: 139 -145.

Sack, R. G. (1983). Semen quality in relation to semen preservation. J. of Dairy Sci., 66: 2635 - 2644. 
Soltan, M. E., A.A. Enab, G. M. Gebril, Kh. Roushdy and Abeer, Y. Sweed (2018). Direct selection response for mature egg weight, egg number, interval between clutches and cltch size in Sinai fowels by using general selection index. Ph. D. Thesis, Poultry and Fish Production Department, Faculty of Agriculture, Menoufia University.

SPSS (2011). SPSS 11.0 for Windows. SPSS Inc., Chicago. Standardization administration of china. 2005.

Tyler, N. and H., Bekker (2012). The effect of dietary crude protein on the fertility of male broiler breeders. South African J. of Anim. Sci., 42: 304 - 309.

Ugurlu, M., F. Akdag, B. Take and M. Salman (2017). Effect of protein in diet and sex ratio on egg production, egg and hatching chick's weight, fertility, hatchability and embryonic mortality in Pheasants (Phasianus Colchicus). Braz. J. of Poul. Sci., 19 (2): 231 - 238.

Van Emous, R. A., C. E. Delacruz and V. D. Naranjo (2018). Effect of dietary crude protein level and age at photo stimulation on reproductive traits of broiler breeders and progency performance. Poul. Sci., 0: 1 12.

Wilson, J., G., McDaniel and C., Sutton (1987). Dietary protein levels for broiler breeder males. Poul. Sci., 66: $237-242$.

Wilson, J.L., L.M., Krista, G.R. McDaniel and C.D., Sutton (1988). Correlation of broiler breeder male semen production and testes morphology. Poult. Sci., 67: 660 - 668.

Wolc, A., I. M., White, V. E., Olori and W. G., Hill (2009). Inheritance of fertility in broiler chickens. Genetics Selection Evolution, 41: 47.

Zhang, X., W., Berry, G., McDaniel, D., Roland, P., Liu, C., Calvert, and R.,Wilhite (1999). Body weight and semen production of broiler breeder males as influenced by crude protein levels and feeding regimens during rearing. Poul. Sci., 78: 190 - 196. 


\title{
الإحتياجات الغذائية من البروتين لذكور دجاج سيناء
}

\author{
محم السيد سلطان و منال كمال أبو النجا \\ قسم إنتاج الدواجن والأسماكـ كلية النزاعةـ جامعة المنوفيةـ شبين الكوم- المنوفيةـ مصر.
}

أجريت هذه الدر اسة لتقدير الإحتياجات الغذائية من البروتين لذكور سلالة دجاج سيناء البدو كسلالة محلية وذلك بتغذيتها على مستويات

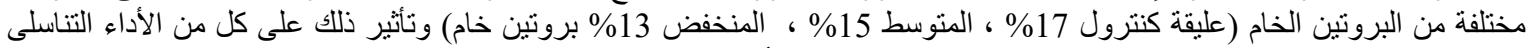

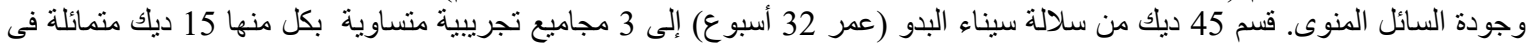
الوزن (1.4 كجم) وقسدت كل مجمو عة إلى 3 مكررات تبكل منها 5 ديوك تم تسكينها في أقفاص فر فردية.

أوضحت النتائج إنخفاض معنوى فئ كمية الغذاء و البروتين المأكول بانخفاض مستوى بروتين العليقة حيث سجلت المعاملة التى تم تغذيتها

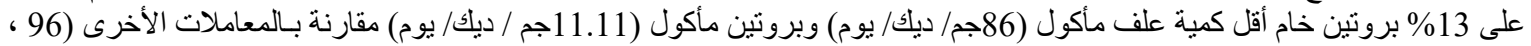

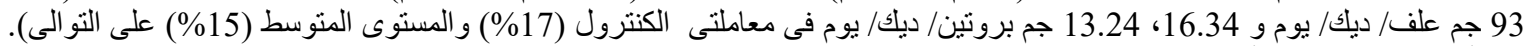

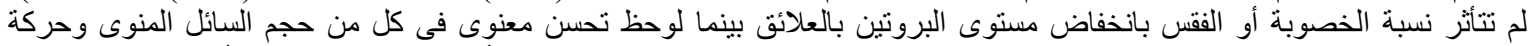

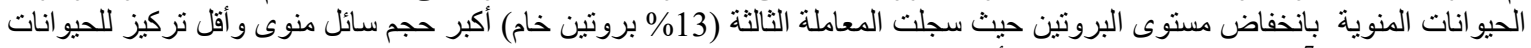

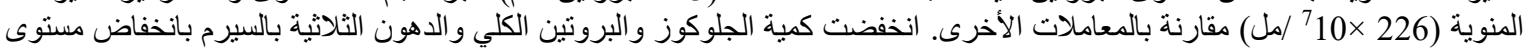

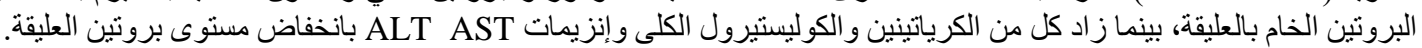

